4. Haug W. Von der Idealität des arthurischen Festes zur apokalyptischen Orgie in Wittenwilers ,Ring'. Poetik und Hermeneutik. 1989. № 14. P. 157-179.

5. Lienert E., Wolter D.. Die Rabenschlacht. Tübingen: Max Niemeyer, 2005. 314 p.

6. Sowinski B. Kompositions-und Gattungsfragen zu Heinrich Wittenwilers ,Ring'. Sprachgeschichte als Textsortengeschichte. Festschrift zum 65. Geburtstag von Gotthard Lerchner. 2000. P. 133-146.

7. Wittenwiller H. Der Ring. Berlin: W. de Gruyter, 2012. 538 p.

DOI https://doi.org/10.30525/978-9934-26-039-1-56

\title{
ЛЕКСИКОГРАФІЧНЕ ВІДОБРАЖЕННЯ КОНЦЕПТУ «КРАСА» В АНГЛІЙСЬКИХ ФРАЗЕОЛОГІЗМАХ
}

\author{
Ярова Л. О. \\ кандидат педагогічних наук, \\ дочент кафедри перекладу, прикладної та загальної лінгвістики \\ Центральноукраӥнського державного педагогічного університету \\ імені Володимира Винниченка \\ Поліщук Г. В. \\ кандидат філологічних наук, \\ дочент кафедри англійської мови та методики ї̈ викладання \\ Центральноукраӥнського державного педагогічного університету \\ імені Володимира Винниченка \\ м. Кропивницький, Украӥна
}

Протягом останніх десятиліть в лінгвістиці спостерігається перехід на антропоцентричну парадигму дослідження, де в центрі уваги дослідників перебуває комплекс проблем, пов'язаних із взаємодією людини і мови, що зумовили зростання інтересу до концепта, який пов'язаний із вмістом суб'єктивного ментального світу людини та ментальної свідомості нації в цілому. Отже, вивчення концептів дозволяє виявити національнокультурну специфіку мовної картини світу тієї чи іншої мовної спільноти, описати менталітет носіїв мови за допомогою аналізу мовних засобів, що якнайкраще відображено у фразеологізмах, оскільки в них не лише закарбована вікова народна мудрість, ціннісна картина світу нації, але й в афористичній формі міститься сума активних і пасивних знань 216 
про зовнішній порядок речей і внутрішній світ людини [5, с. 13]. Одним iз центральних концептів англійської лінгвокультури є концепт «краса», який разом $з$ добром та істиною визначає найголовніші цінності людства, виступає як загальнолюдська категорія, оскільки є універсальним для більшості мов світу і як поняття культури, тобто, складаючись в рамках англійської культури, наділений i національною специфікою. Дослідження різних аспектів концепту «краса» було предметом аналізу багатьох науковців: Ю.В. Мещерякова (на матеріалі російської та англійської мов) [7]; В.3. Дем'янков (російська, англійська, німецька, французька мови) [3]; Н.В. Летуновська (німецька, російська мови) [6], Л.І. Даниленко (чеська) [2]; О.М. Цапок (українська) [8], Ю.П. Андрушко (російська) [1]; О.В. Дудченко (англійська мова) [4] та ін. Однак, незважаючи на постійний інтерес мовознавців до концепту «краса», недостатня увага приділена вивченню особливостей реалізації даного концепту в англійських фразеологізмах, отже, вирішено проаналізувати мовні засоби вираження концепту «краса» в англійській лінгвокультурі шляхом теоретичного аналізу наукової літератури 3 теми 3 метою відбору та систематизації фактичного матеріалу; шляхом суцільного обстеження The Penguin Dictionary of Proverbs (1995) [10] та інтерпретації отриманих даних за допомогою Longman Dictionary of English Language and Culture (2000) [9]. У межах нашої роботи продуктивним для концептуального аналізу вважаємо звернення до фразеологізмів.

Аналіз експериментального матеріалу (240 фразеологічних одиниць) дозволяє констатувати, що, по-перше, в англійських фразеологізмах, прислів'ях та приказках наголошується на чуттєвому задоволенні від краси: sight for sore eyes, на оманливості зовнішності, невідповідності зовнішнього і внутрішнього: beauty is but skin deep, all that glitters is not gold, appearances are deceptive, fair without, false within, a fair face may hide a foul soul, fine words dress ill deeds, handsome apples are sometimes sour, many a rosy apple is rotten to the core, pretty shoe often pinches the foot, beauty may have fair leaves, yet bitter fruit тощо, що складає 47\% випадків у матеріалі спостереження. У цьому контексті неодноразово знаходимо застереження від поверхневих суджень про об'єкт: don't judge a book by its cover, don't value a gem by its setting, don't trust so much in an enchanting face. При співвіднесенні зовнішньої i внутрішньої краси перевага надається красі й багатству внутрішнього світу людини: there is no beauty like the beauty of the soul, beauty comes from the soul. Цікаво, що в англійській картині світу краса проголошується не менш важливою цінністю, ніж честь і совість: good fame is better than a good face, handsome is as handsome does, beauty may open doors, but only virtue enters 
тощо; у прислів'ї beauty is in the eye of the beholder викрито суб'єктивність сприйняття краси відповідно до уявлень про прекрасне самого спостерігача.

По-друге, нами встановлено, що, з одного боку, існує переконання, що зовнішня форма - це не головне (looks aren't everything, clothes don't make the men), 3 іншого, значної уваги приділено саме зовнішньому вигляду (fine feathers make fine birds), по якому судять про людину. Оскільки одяг $\epsilon$ прикрасою людини, то за допомогою вдалого вибору $\mathrm{i}$ поєднання предметів одягу можна зробити привабливим навіть тих, хто не наділений природною красою: clothes make the man, no woman is ugly if she is well dressed тощо (16\%). У фразеологізмах, прислів'ях і приказках підкреслюється, що красива зовнішність $є$ перепусткою у світ широких можливостей, краса $є$ способом досягнення бажаних цілей (good clothes open all doors, to travel on/run one's face) тощо; зовнішність людини розглядається як товар (3\%), якість якого визначається його вартістю: to look like a million dollars; асоціація багатих, відомих людей із гарною зовнішністю покладена в основу ідіоми beautiful people, а позитивна оцінка зовнішності втілена в наступних образах англійських порівнянь (4\%): квітів (as red as a rose, as fresh as a daisy); птахів (as graceful as a swan); божества (as an angel); витворів мистецтва (pretty as a picture, handsome as paint); м'якості шовку (as fine as silk); блискучої монети (as fine as fivepence) тощо. Також варто зауважити, що саме в ідіоматичних виразах beauty mark (spot, parlour, salon, shop, sleep; queen, contest; myth) актуалізуються ознаки «створення або підсилення краси», «визначення найкрасивіших», «невірні уявлення про красу» тощо.

Особливого значення в англомовній картині світу зовнішність набуває для жінки, оскільки врода $є$ не тільки основною прикрасою жінки, ії головною «зброєю», а й запорукою успіху в житті (her face is her fortune, beauty is a wisdom of women, wisdom is the beauty of men, she who is a beauty is half-married) (18\%). Ми зафіксували, що в англійських прислів'ях підкреслюються конкретні риси саме жіночої зовнішності, які найчастіше стають об'єктом позитивної оцінки: обличчя, волосся, тонка талія (her face is her fortune, a woman's hair is her crowning, narrowness of waist shows narrowness of mind). Водночас спостерігається і протилежний погляд на зв'язок краси і успіху: часто навіть гарні на вигляд люди бувають нещасливими, що найкраще ілюструє протиставлення pretty face, poor fate.

У матеріалі дослідження знаходимо уявлення англійців щодо тривалості краси, прекрасного, наприклад, beauty is a fading flower, beauty is a blossom, prettiness dies first, але задоволення, отримане від сприйняття 
прекрасного, залишається надовго (a thing of beauty is a joy forever). Привертає увагу песимістичне твердження про ефемерність краси $\mathrm{i}$ тривалість потворності: beauty dies and fades away, but ugly holds its own тощо (7\%); підтвердження несумісності краси та розуму: beauty and brains don't mix, long hair and short wit, beauty and folly are old companions, narrowness of waist shows narrowness of mind тощо (5\%); наявність інтелектуальних здібностей у красивої людини вимагає додаткового уточнення: not just a pretty face.

Краса $є$ результатом любові: закоханим властива ідеалізація своїх обранців, бачення їх у прикрашеному вигляді (beauty lies in lover's eye), тому їхня оцінка не є об'єктивною: Jack is no judge of Jill's beauty, переконання у могутній силі краси, іiі магнетизмі розуміється двояко: 3 одного боку краса приваблює увагу та інтерес (beauty draws with a single hair, beauty draws more than oxen), 3 іншого - притягує неприємності (beauty provokes thieves sooner than gold).

Отже, у результаті обстеження фразеологічного словника нами встановлено, що концепт «краса» широко представлений в англійських фразеологізмах через свою виняткову значущість для англійської лінгвокультури: наголошується на чуттєвому задоволенні від краси, акцентовано на суб'єктивності сприйняття красивого, оманливості зовнішності, ефемерності краси, іiі несумісності з розумом $(47 \%)$, перевага надається красі й багатству внутрішнього світу людини, аніж зовнішньому, приділено увагу зовнішньому вигляду, особливо жіночій зовнішності (18\%). У перспективі подальших наукових розвідок планується порівняльний аналіз фразеологізмів 3 концептом «краса» в українській, російській та німецькій мовах.

\section{Література:}

1. Андрушко Ю.П. Проблема красоты в малой прозе писателейдекадентов. Литература в контексте современности. Челябинск, 2005. Ч. 2. С. $154-158$.

2. Даниленко Л.І. Мовно-образний простір чеської ментальності: концепт «краса». Мовознавство. 2006. № 2/3. С. 147-152.

3. Демьянков В.З. Значение и употребление лексем класса «красота». Сокровенные смыслы: Слово. Текст. Культура. М.: Языки славян. к-ры, 2004. С. 601-609.

4. Дудченко О.В. Реконструкция концептосферы красота в англосаксонской картине мира: Автореф. дис. канд. фил. наук: 10.02.04: Владивосток, 2007. 22 с. 
5. Клинцова Ю.В. Лексико-семантические и когнитивно-деривационные аспекты гиперконцепта «красота» (на мат. англ. и рус. языков): Автореф. дис. канд. фил. наук: 10.02.19: Краснодар, 2007. 22 с.

6. Летуновская Н.В. Лексико-семантическая репрезентация концепта «красота» в немецком и русском языках: Дис. канд. фил. наук: 10.02.20: Тамбов, 2005. $173 \mathrm{c}$.

7. Мещерякова Ю.В. Концепт «красота» в английской и русской лингвокультурах : Автореф. дис. канд. филол. наук: 10.02.20: Волгоград, 2004. $24 \mathrm{c}$.

8. Цапок О.М. Мовні засоби репрезентації концепту краса в поезії українських шістдесятників: Автореф. дис. канд. філ. наук: 10.02.01/Одеса: Одес. нац. ун-т ім. I.I. Мечникова. 2004. 20 с.

9. Longman Dictionary of English Language and Culture. 3rd Edition. Pearson ESL, 2000. 1584 p.

10. The Penguin Dictionary of Proverbs. London: Claremont Books, 1995. 352p. 